\title{
Contribution of Unit Managers to the Training of Student Nurses in the Cape Peninsula
}

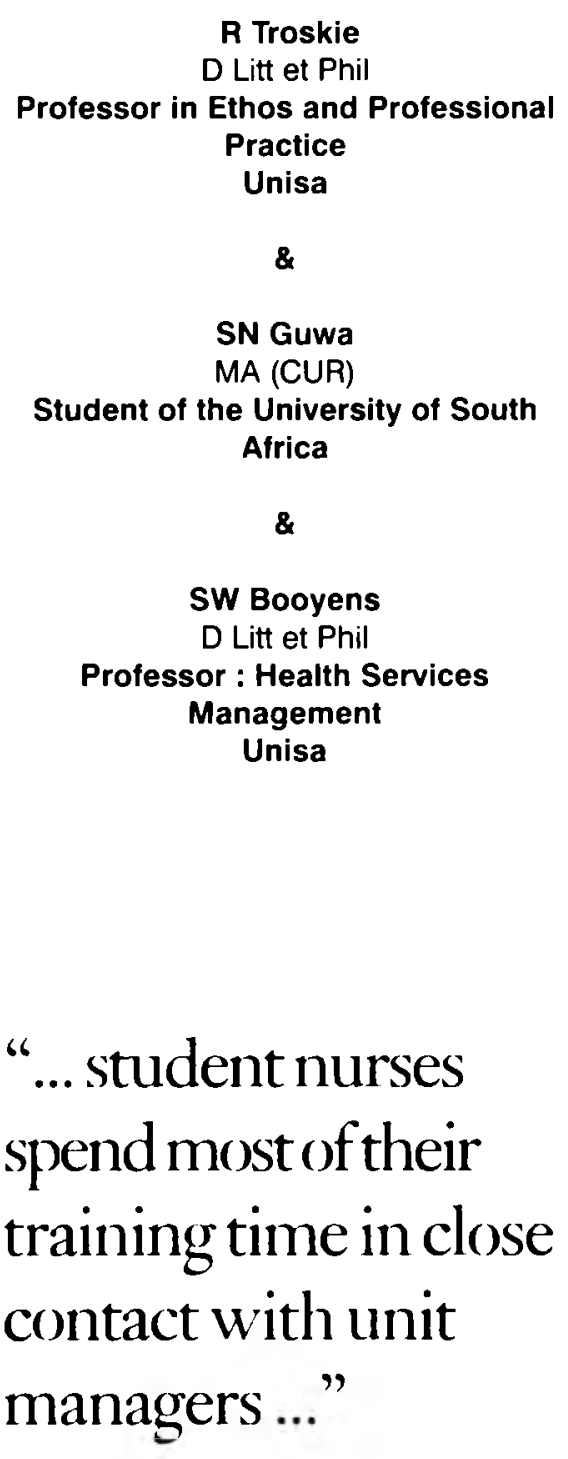

\section{Research Article}

\section{Abstract}

The article is based on research conducted over the period 1993 to 1996 in the Cape Peninsula. The purpose of the study was to determine the contribution of unit managers towards the training of student nurses coming to their units for clinical practica. The sample consisted of student nurses training in the four nursing colleges in the Cape Peninsula, and the unit managers working in the health services accommodating students for clinical practica in the same area.

The findings revealed that the majority of unit managers were teaching students whenever they had the opportunity. Generally unit managers were prepared for their teaching function, but many students were not satisfied with some clinical learning opportunities presented to them, for example drawing up patient care plans, discussing patients' treatment plans when handing over report, giving assistance regarding care decisions and lending support when students are confronted with patient care problems. There appears to be a need to educate unit managers regarding these and other aspects of the students' training programme.

\section{Abstrak}

Hierdie artikel is op navorsing gebaseer wat in die periode 1993 tot 1996 in die Kaap Peninsula gedoen is. Die doel van die studie was om te bepaal wat die bydrae van eenheidbestuurders in die opleiding van kliniese praktika, vir studentverpleegkundiges, in hulle eenhede is. Die steekproef was studentverpleegkundiges in die vier verpleegkolleges in die Kaap Peninsula en eenheidbestuurders wat werksaam is in die gesondheidsdienste wat die studente vir hulle kliniese praktika akkommodeer in dieselfde area. Die bevindinge het aangetoon dat die meerderheid eenheidsbestuurders, wanneer die geleentheid hom voordoen, wel studente onderrig. In die algemeen was eenheidsbestuurders voorberei vir hullle onderrigfunksie, maar baie studente was nie tevrede met sommige van die kliniese leergeleenthede wat aan hulle gebied is nie. ' $n$ Voorbeeld hiervan is by die opstel van verpleegsorgplanne, bespreking van die pasiënt se behandeling tydens die oorhandiging van verslag, hulp ten opsigte van besluite wat die versorging van die pasiënt raak en die gee van ondersteuning wanneer studente met probleme van die pasiënt te doen kry. Daar blyk dus 'n behoefte te wees om eenheidsbestuurders op te lei in dié verband en in ander aspekte van die student se opleidingsprogram.

\section{Introduction}

In South Africa student nurses spend most of their training time in close contact with unit managers. It is therefore important that unit managers carry out their roles and functions in a manner that will ensure student nurses' professional growth. With the introduction of the fouryear comprehensive course (SANC R425:1985) the status of the student nurse remained unchanged. Students were forced to participate actively in unit activities because of a staff shortage. This had a detrimental effect on training because students were regarded as part of the workforce (Viljoen 1989:25-26).

Because of the multidimensional role of the unit manager and the staff shortage, patient care took priority and student teaching fell behind. Another issue which surfaced when the new programme was implemented was that unit managers were not well versed in the training curriculum and needed in-service training. It was difficult for them to assess the students' learning needs and what was expected of them (Jooste 1991:1). Some colleges appointed clinical tutors to accompany students in the different health units. The shortage of tutors made it difficult for one tutor to spend enough time with each student. It is, therefore, wise to use unit managers, empowering them to train students allocated to their units. 


\section{Background to the problem}

As the foundation of learning to nurse is found in the health service units - be they midwifery, general, psychiatry or community health nursing - one cannot overemphasize the importance of the role played by unit managers, for they are responsible for quality patient care, the management of day to day activities and the supervision and training of subordinates. Gerrish (1990:200) describes clinical teaching as the core of nursing practice and states that clinical skills are best taught by practising nurses in the real situation.

Lack of time to teach, lack of a knowledge base and teaching skills, lack of confidence in their teaching abilities, lack of expert specialist help with teaching and the inability to assess learner needs are some of the problems related to teaching by unit managers (Runciman 1983:68). Bezuidenhout (1988:8) found in a study conducted in the then Transvaal that the fact that student nurses are both learners and workers is frustrating to them. When unit managers are young and inexperienced, students have difficulty approaching them with their problems, as they often see them as someone without status and confidence. It is therefore important that unit managers receive support from tutors, to assist them with their teaching function (Bezuidenhout 1988:8).

\section{Problem Statement}

According to Bezuidenhout (1988:2-3) a combination of factors are responsible for problems experienced in the effective provision of independent, professional practitioners. A shortage of well-prepared registered nurses to fulfil their clinical teaching function causes student nurses to feel insecure in their working environment. These young adults are expected to perform a variety of duties and to accept responsibility for performing them without the necessary guidance. The perceived lack of involvement of unit managers in the clinical teaching of student nurses in the Cape Peninsula gave rise to this study to explore to what extent unit managers are involved with clinical teaching, whether they are sufficiently prepared to take on this role and to meet the learning needs of student nurses.

\section{Statement Of Purpose And RescarchQuestions}

The purpose of the study is stated in the questions that guided the study. These questions are the following:

- Are unit managers sufficiently prepared to provide teaching in the units?

- To what extent are the unit managers involved in the clinical teaching of students in the units?

- To what extent are student nurses satisfied with the type of clinical learning opportunities that are presented to them?

\section{Operational Definitions}

Clinical teaching is the practice-oriented teaching given to students in laboratory practice situations and these include the service units (SANC R425:1985).

Health service unit refers to a hospital ward or department or a community health centre where health care is given to clients/patients (Hawkins \& Weiner 1990:780).

Learning opportunity refers to the possibilities for learning created by the tutor in the classroom and clinical teaching situations which are used by the student to reach learning objectives (SANC R425:1985).

Student nurse refers to an individual who is presently undergoing the required training which has a minimum duration of four years, to fulfil SANC's requirements to become a registered professional nurse (general, psychiatry and community) and midwife (SANC R425:1985).

Unit manager is synonymous with the nurse who is in charge of a health team which cares for a specific group of patients/clients within the boundaries of the unit (Lees 1989:8).

\section{Review of Literature}

A review of the literature was done to determine the role of the unit manager in a health service setting in training student nurses. The different learning opportunities present in a particular unit determine whether the required learning takes place. It is important for students to be in a unit where it is possible to correlate theory with practice as these two elements should reinforce and complement each other (Jacka \& Lewin 1986:573). Unit managers, however, experience role ambiguity because of unclear role expectations and uncertainty about work performances and behaviours. Sometimes there is conflict between what unit managers perceive as their role in relation to teaching and the expectations students have of them. Often the unit manager is expected to perform teaching and management duties at the expense of the clinical role (Marson 1984:13-16). Unit managers should, however, be aware that student nurses in their units are not just part of the working force, but have come to the unit to learn their profession. As an expert in her or his field the unit manager is responsible for the professional growth of the student (Jooste \& Troskie 1995:13). Feedback on their performance is a learning/teaching opportunity and should be a true reflection of the student's performance and abilities (Jooste 1991:33-35). The unit managers' attitude to their duties influences the teaching environment in the unit. If unit managers see patient care as a priority they work with the students and teach them as the opportunity arises (Fretwell 1982:99). If their attitude to teaching is positive the learning opportunities will be used to teach students.

Clinical teaching is the most important function of the unit managers, because it lays the foundation for the improvement and maintenance of nursing standards. Nursing can be effective only if the quality of the professional practice of unit managers is good and they are prepared to teach, to manage and to care for their patients effectively.

\section{Mcthodology}

A quantitative descriptive method of research was used because the main objective of the study was to portray accurately the contributions of unit managers and the frequency with which certain phenomena occur in the training of student nurses. Consent to conduct the study was obtained from the DirectorGeneral of Health in the Western Cape Province as well as the nursing colleges, hospitals and community health centres where the research was conducted.

Target population

The population consisted of unit managers who supervise student nurses in hospitals and community centres in the Cape Peninsula as well as student nurses who are assigned to the different units for their clinical practica. The student nurses were doing the four year course and were in their fourth year of study in the four nursing colleges in the Cape Peninsula.

Sampling

Seven institutions were selected because most of the learning institutions and colleges send their students to these hospitals and community centres for their different learning experiences. A sampling frame was formed from all the units which are used in the health services that were identified. The units were randomly selected. A total of 117 units from a total of 230 were selected. The student nurses were chosen from fourth year students who were writing their final examination in July and November 1995. A total of 50 student nurses per college were chosen. The total sample size was 200. The unit managers were randomly selected from a total of 455 , the sample size being 155 .

\section{Research instrument}

Two computer coded questionnaires, one for unit managers and the other for student nurses, were drawn up and include both closed and open-ended questions. Both these questionnaires 
have 50 similar items, divided into five sections, to get answers to the research questions.

Reliability and validity

The Cronbach Alpha Coefficients were computed for the entire scale, questions 4 to 50 , as well as each of the four factors that rotated. A meaningful comparison of alpha coefficients across scales was possible and all Cronbach Alpha values were very high, which indicates that the constructs are measured reliably. A trial run was also used to test the reliability of the instrument.

Validity was ensured by the supervisor, clinical tutors and supervisors in the field and a statistician critically evaluating the questionnaires. Discrepancies and errors were corrected as suggested.

Datacollection

\section{Ethical considerations}

The prospective respondents were informed of the purpose and method of the research and thus voluntary participation was ensured. All participants were ensured that they would remain anonymous.

Method of distribution and return of questionnaires

The different institutions were phoned and appointments were made with the contact persons. The questionnaires were discussed with them after which they agreed to help with the distribution to preselected respondents. Of the 155 questionnaires sent to unit managers 128 $(82 \%)$ were returned and of the 200 questionnaires to students $146(77,1 \%)$ were returned.

\section{Data Analysis and Research Findings}

A factor analysis was done and although six factors rotated, only four were represented by a substantial number of items. The four factors will be discussed as they relate to the research questions. The four factors that rotated were as follows:

- $\quad$ Factor 2 related to question 1: To what extent are the unit managers involved in clinical teaching of students in the units?

- $\quad$ Factor 1 and factor 3 related to question 2: To what extent are the unit managers involved in clinical teaching of students in the units? - $\quad$ Factor 4 related to question 3: To what extent are student nurses satisfied with the type of clinical learning opportunities that are presented to them?

Descriptive profile of the sample

It was found that the age of the unit managers who participated in the study ranged from 24 to 63 years with a mean of 38,7 . Of the unit managers 87 percent were between the ages of 30 and 49 years. The majority were trained in general nursing and midwifery and few had qualifications in nursing education and nursing administration.

From the analysis it is deduced that the unit managers were of a mature age and that the majority of student nurses were still young as their ages ranged between 19 and 29 years with an average of 23,8 years. It seems that most of them started their training at the age of 19 years.

Are unit managers sufficiently prepared to provide teaching in the units?

The items that rotated in factor 2 which answered the research question on the preparedness of unit managers for their teaching function were: attending inservice training sessions for trained staff participating in drawing up in-service education programmes, active involvement in presenting in-service education, attending and organising symposia, contact with training colleges and coordination with college staff.

Ninety-five percent of the unit managers stated that they regularly attended inservice education programmes for trained staff. This was supported by 79 percent of the student nurses. It is thus obvious that most unit managers made full use of in-service training opportunities presented to them. A large number of unit managers $(76 \%)$ stated that they participated in drawing up educational programmes for trained staff, which was confirmed by 65 percent of the student nurses.

Unit managers who attend in-service training are up to date with what is going on in their profession and are equiped with skills and knowledge to meet the demands of their current jobs (Jooste \& Troskie 1995:49). Figure 1 gives a picture of the responses to this research question by both groups. Although 76 percent of the unit managers attended symposia, a

'Table 1: Comparison of between student nurses' and unit managers' perception regarding meeting of students' clinical teaching noeds

\begin{tabular}{|c|c|c|c|c|}
\hline & \multicolumn{2}{|c|}{ Unit managers $N=126$} & \multicolumn{2}{|c|}{ Student nurses $N=138$} \\
\hline Agree & 118 & $(93,6 \%)$ & 79 & $(56,8 \%)$ \\
\hline Disagree & 8 & $(6,4 \%)$ & 60 & $(43,2 \%)$ \\
\hline TOTAL & 126 & $100 \%$ & 139 & $100 \%$ \\
\hline
\end{tabular}


Figure 2: The teaching and evaluation function of the unit manager

Unit manager $(N=128) \quad$ Student nurses $(N=140)$

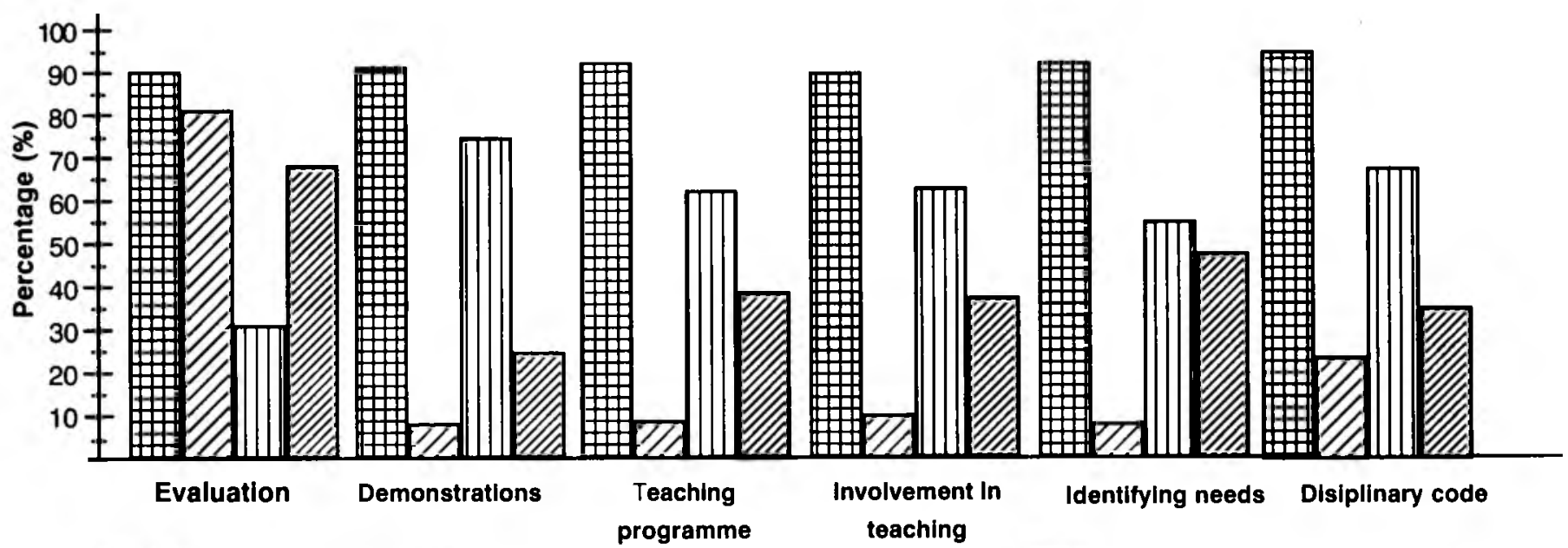

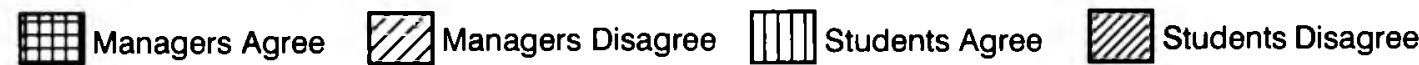

fact supported by 63 percent of the student nurses, only a small percentage (49\%) according to unit managers and 45 percent according to the student nurses are directly involved in organising symposia. This is to be expected as unit managers have limited opportunities participating in the organisation of symposia. Attending symposia gives unit managers the opportunity to discuss some of the developments in nursing as well as current issues related to training of student nurses.

Days arranged by the colleges to inform unit managers of students' training programmes are attended by 61 percent of the unit managers in the study, and 68 percent contact colleges to update themselves on new developments related to student training. Only $\mathbf{4 9}$ percent of the student nurses agreed with this, but this could be because students are not always aware of the contact unit managers have with the colleges. According to Hincliff (1986:49) training programmes should be based on students' learning needs and any new developments should be accommodated. To ensure that this is done in the units, regular contact with the nursing colleges is essential and it is encouraging that unit managers are aware of the importance of having contact with the college staff. As unit managers are organising and attending in-service education programmes and also attend symposia to keep themselves updated on the latest developments in nursing education, it would appear that they do in fact prepare themselves for their teaching function. Coordination with the colleges also receives attention.

'Io what extent are the unit managers involved in the clinical teaching of students in the units?
Factor 1 and factor 3 represent the items related to the extent to which unit managers are involved in the clinical teaching of student nurses in the units. The items included in these factors are unit managers' knowledge level of the clinical training needs of student nurses, writing problem-oriented patient records, handing over reports, assisting in decision making, supporting students when doing procedures and counselling students.

Although 93,6 percent of the unit managers indicated that they met the clinical learning needs of the student nurses, a substantial number of students $(43 \%)$ felt that their clinical learning needs were not met, as shown in table 1. This is of concern because students need to learn from practical experience how to perform certain tasks and need guidance in making decisions.

Although 94 percent of the unit managers indicated that they teach student nurses how to write problem-oriented nursing records, this was only supported by 65 percent of the student nurses. With a significant difference of 29 percent it can be assumed that students are not sufficiently involved in writing problemoriented records. This is also supported by a 23 percent difference in the responses to a question about whether students are supported sufficiently when drawing up patient care plans. Support for students when a patient's condition deteriorates is not always available as the significant difference of $\mathbf{4 2}$ percent in the unit managers' and student nurses' responses indicates. Students faced with such a stressful situation need the support of the unit manager. Bezuidenhout (1988:23) indicates that managers have to teach students to observe any untoward changes in a patient's condition and to act calmly and swiftly, in a caring manner. Students $(35,9 \%)$ also did not agree that they received the necessary guidance when performing procedures and 32,4 percent did not perceive the unit managers as role models.

Table 2 indicates the responses of both unit managers and student nurses to the support given to student nurses when they experience problems.

\section{Table 2: Comparison of student nurses' and unit managers' perception} regarding the support given to student nurses when they experience problems

\begin{tabular}{|c|c|c|c|c|}
\hline Problems & \multicolumn{2}{|c|}{ Unit managers $\mathrm{N}=126$} & \multicolumn{2}{|c|}{ Student nurses $N=138$} \\
\hline Patient-care problems & 121 & $(95 \%)$ & 94 & $(68 \%)$ \\
\hline Management problems & 118 & $(94 \%)$ & 80 & $(57 \%)$ \\
\hline $\begin{array}{l}\text { Counselling for } \\
\text { personal problems }\end{array}$ & 90 & $(73 \%)$ & 51 & $(37 \%)$ \\
\hline
\end{tabular}


Although 95 percent of the unit managers indicated that they give the necessary support when students are confronted with patient-care problems, only 68 percent of the student nurses agreed with the statement. An even poorer response was received on support when faced with management problems where only 57 percent of the students agreed that they received support. Counselling when experiencing personal problems seems to be an even bigger problem as only 37 percent of the student nurses felt that they received support from the unit manager in this regard and 27 percent of the unit managers did not give support when student nurses have personal problems. Unit managers may feel that they are not competent to handle other people's personal problems and should, therefore, receive the necessary training to enable them to assist or to refer the person if necessary.

To what extent are student nurses satisfied with the type of clinical learning opportunities that are presented to them?

Items in factor 4 that indicate the response as to what extent student nurses are satisfied with the type of clinical learning opportunities that are presented to them are the following: orientation of student nurses in the units; setting objectives to enhance learning; providing teaching aids and drawing up a programme for teaching in the units.

Only 50 percent of the student nurses were satisfied that unit managers draw up checklists to ensure that they receive the necessary orientation to the units. Student nurses (82\%) were, however, satisfied that unit managers were actively involved in presenting orientation programmes.

In contrast to 89 percent of the unit managers, only 53 percent of the student nurses felt that there were sufficient teaching aids in the units. The difference could be because of different interpretations of the term "teaching aids" by the two groups. Students in general felt that unit managers were not sufficiently involved in teaching student nurses. It is encouraging to note that in contrast with dissatisfaction with evaluation of students' progress, drawing up a teaching programme and involvement of unit managers with teaching in the units, student nurses are satisfied with demonstrations received in the units.

Students (44\%) do not feel that they are satisfactorily involved in sharing information with the multidisciplinary team, they $(47 \%)$ are not sure of how referrals are made and do not participate in conferences with the other members of the multidisciplinary team. Unit managers have to be skilled in cooperating with everyone who is concerned with patient care and have to coordinate all the activities in the unit. Fourth year student nurses need to be taught how to do this as they will shortly be the nurse in charge of the unit.

\section{Rourmmendations}

The findings indicate that most unit managers who participated in the study are adequately prepared for their teaching function in the units. It is therefore essential that unit managers should receive ongoing training to keep them informed of new developments in the training of student nurses. Liaison with the college is an essential component of this preparation. Regular meetings with the college staff should form an integral part of the unit managers' in-service training programme.

Student nurses in the study felt that their needs for clinical teaching is not met sufficiently by unit managers. This could result in frustration and students being bored because they are not taught things relevant to their training. Students should be taught how to draw up patient care plans at least once a month or, whenever a patient is admitted to the unit. On regular ward rounds unit managers should accompany student nurses and check patients' records. Student nurses should be assisted in making nursing decisions, according to the patients' condition. Unit managers should work with students more often to be able to evaluate performance and correct and teach on the spot. Other members of the multidisciplinary team should be afforded the opportunity to participate in the training of student nurses. Unit managers should act as caring and resourceful mentors and a support system should be put in place for students who need professional help

As not all students are satisfied with the manner in which their learning needs are identified and objectives are set to draw up a clinical teaching programme, unit managers should have interviews with students when they come to the units to set their learning objectives with them. This would enable the unit manager to draw up a clinical programme to teach student nurses the aspects relevant to their learning needs. Active participation of unit managers in planning and presenting clinical teaching programmes will enhance learning. Teaching aids such as overhead projectors, chalkboards and pamphlets should be made available to support the teaching process and case studies should be used to guide students in the nursing care of patients. Evaluation of students' progress should play a major role in the unit manager's teaching function. Students should be given the opportunity to inform unit managers when they are ready for evaluation. Evaluation should be discussed and measures for improvement planned with the student.

\section{(ionclusion}

It is apparent from the research findings that some unit managers do teach student nurses when they have the opportunity. Unit managers are also prepared for their teaching functions, but need the support of the colleges to ensure that students' learning needs are met. A reasonable number of student nurses are satisfied with the clinical learning opportunities presented to them. There were, however, a large enough number of the student nurses who were of the opinion that they did not receive the necessary support and guidance from unit managers in the units regarding clinical patient care aspects. This warrants attention and rectification. 


\section{Referenoes}

Bezuidenhout, MC. 1988. Die opleidingsfunksie van die geregistreerde verpleegkundige in 'n hospitaal. Ongepubliseerde MA Cur verhandeling, Johannesburg: RAU.

Fretwell, JE. 1982. Ward teaching and learning - sister and the learning environment. London: Royal College of Nursing.

Gerrish, CA. 1990. An analysis of the educational role of the ward sister (implication for nurse educators). Nurse education today, 10(3):198-205.

Hawkins, JM \& Weiner, ECS. 1981. The illustrated family dictionary. Hertsford: Wordswork.

Hincliff, SM. 1986. Teaching clinical nursing. Edinburgh: Churchill Livingstone.

Jacka, K \& Lewin, D. 1986. Elucidation and measurement of clinical learning opportunity. Journal of Advanced Nursing, 11(5):573-582.

Jooste, K. 1991. Die verpleegkundige in beheer van 'n eenheid as preseptor in personeelontwikkeling in opleidingshospitale in Namibië. Ongepubliseerde MA Cur verhandeling, Pretoria: Unisa.

Jooste, K \& Troskie, R. 1995. Staff development for nurses. Halfway House: Southern.

Lees, A. 1989. Die bydrae van eenheidsbestuurders in die opleiding van studentverpleegkundiges. Ongepubliseerde MACur verhandeling, Johannesburg: RAU.

Marson, SN. 1984. Developing the teaching role of the ward sister. Nurse education today, 4(1):13-16.

Runciman, PJ. 1983. Ward sisters at work. Edinburgh: Churchill Livingstone.

SANC. 1985. Regulation relating to the approval of and the minimum requirements for the education and training of a nurse (general, psychiaty and community) and midwife leading to registration. Regulation R425 in terms of the Nursing Act 50 of 1978 as amended.

Viljoen, JM. 1989. Onderwys simposium: 'n D4 perspektief - Instelling van die D4 kursus in die Kaapprovinsie. Ann Latsky Verpleegkollege:14-27. 